Vukov Anikó Veronika

\title{
ANGYALKÁRTYÁTÓL A SPORTOLÓ BELSŐ EREJÉIG - EGY „GYÓGYítÓ NAP” BEMUTATÁSA
}

\author{
DOI 10.35402/kek.2019.2.9
}

Célom egy, az egészségtudatosság jegyében szervezett rendezvény programjait, kínálatát bemutatva rávilágítani napjaink alternatív gyógyászatának meghatározó narratíváira.

A vizsgált rendezvény a II. Elixirek, esszenciák testnek és léleknek - gyógyitó nap az egészségedért! mely 2018. április 14-én zajlott. Az első ilyen nap közel egy évvel ezelőtt, 2017 márciusában került megrendezésre. Kapitány Ágnes és Kapitány Gábor Egészségkultusz - biokultusz - természetkultusz címmel írt könyvfejezetükben (Kapitány - Kapitány 2013:94-132) számos példával illusztrálják az ezredforduló utáni alternatív gyógyászati jelenségeket. Az ő megállapításaikat használom a másodjára megrendezett "gyógyító nap" kínálatának bemutatásakor.

A betegséget, mint kulturális viselkedést láttatja Keszeg Vilmos és Czégényi Dóra, mely az egyéni és közösségi attitűdök szintjén észlelhető (Keszeg Czégényi 2015:429). A „gyógyító nap” példájával szeretném bemutatni, hogy ez nemcsak konkrét betegség esetén illetve a konkrét betegségről való beszéd és irányában alkalmazott attitűd vizsgálatakor érhető tetten, hanem a megelőzés és az egészségtudatosság fogalomkörébe tartozó olvasatokból és stratégiákból is kulturális viselkedés(minta) rajzolódhat ki előttünk.

A kutatáshoz a rendezvény helyszínén folytatott résztvevő megfigyelést alkalmaztam. Mivel második alkalommal rendezték meg ugyanezen a helyszínen a "gyógyító napot”, a kutatáshoz kétféle megoldás kínálkozott: a szervezők, ötletgazdák külön megkérdezése a „gyógyító napok” céljáról, a megvalósítás folyamatairól, majd ezután a látogatók későbbi megkeresésekor összevetni a szervezői szándékot és a látogatói reflexiót. A második lehetőség kizárólag az „ott és akkor” vizsgálata: mi volt látható, miről szólt a „gyógyító nap”? A többtermes helyszínen a bőséges és változatos programok meglátogatása után arra jutottam, hogy a tanulságokat az adott napon, a nagyközönség számára látható-hallható eseményekből és kínálatból vonom le, melyek elemzését a sajtó és az esemény facebook-oldala információinak bevonásával mélyítem el. A föszervező moderátori feladatokat is ellátva az előadók és a programok bemutatásakor részletesen indokolta a meghívás okát, a téma hasznosságát, bemutatva így a szervezői elképzeléseket. A látogatói reflexiókat pedig a helyszínen folytatott rövidebb beszélgetések felidézésével mutatom be.

A rendezvény helyszíne a tápéi Heller Ödön Művelődési Ház. Tápé Árpád-kori település, nevét már 1138-ban említette oklevél, 1973-ig Csongrád megye Szegedi járásához tartozott, 1973-ban csatolták Szegedhez. A településről 1971-ben jelent meg monográfia. ${ }^{1}$ Életmódjának régmúltba viszszanyúló elemeit - például viselet, gyékényszövés - sokáig megőrizte a gyorsan változó természeti és gazdasági körülmények ellenére is. Néprajzi jellegzetességeit a művelődési ház emeletén kiállítás és ifj. Lele József magángyűjeménye mutatja be, a tápai gyékényszövés és a tápai búcsú pedig napjainkban is élő hagyomány. Mindezek az erősen jelen lévő identitástudat tápláló forrásai és megnyilvánulási lehetőségei egyben. ${ }^{2} \mathrm{~A}$ helyi identitás a „gyógyító napon” kizárólag a meghívott sportoló, a tápai születésủ olimpikon és világbajnok súlylökő Márton Anita szereplésekor kapott hangsúlyt, melyre a későbbiekben térek ki.

A következőkben az előadások, programok illetve helyszínek részletesebb leírásával mutatom be a „gyógyító nap” kínálatát, stratégiáit, majd a látottakat-hallottakat összegezve adok választ a kérdésre: napjaink alternatív gyógyászatának milyen narratíváit vonultatja fel ez a tematikus rendezvény? Ezután a sportoló szerepeltetését, mint a rendezvény külön tematikus blokkját elemzem, feltárva a lehetséges kapcsolódási pontokat az alternatív gyógyászat narratívái és a sportoló teljesítményeinek méltatása között.

1 Juhász Antal szerk. Tápé története és néprajza. Tápé, 1971.

2 A „tápaiság” nemcsak az egykori zárt hagyományvilágú, mélyen vallásos és Tiszához szorosan kapcsolódó életmódú faluközösséget jelöli, hanem napjainkban is kapcsolódik hozzá narratíva: „Tápén még mindig él egy olyan önazonosság-tudat, amely megkülönbözteti az itt élő embereket a 'szegedi tengertől'. Ez a tápaiság” - nyilatkozta Juhász Gyula, a körzet önkormányzati képviselője 2010-ben. https://szegedma.hu/2010/06/akormorannal-unnepel-tape 
A művelődési házon belül hat helyszínen zajlott a rendezvény: a nagyteremben, a kis tükrös teremben, a kisebb előadó teremben, a könyvtárteremben, az elötérben és az udvaron. A nagytermi elöadásokat a föszervezö és az önkormányzati képviselő beszéde vezette be; utóbbinál megjelent a lokalitás - helyi identitás kiemelése, amint a díszvendéget és a "Tápé település sokszínű programkínálatát" említette. A főszervező-moderátor bevezető szavai, miszerint „arra kérünk mindenkit, hagyja az előítéleteit, fenntartásait az ajtón kívül és törekedjen arra, hogy minél több újdonsággal ismerkedjen meg és gazdagítsa az életét" megalapozták a rendezvény egészén végigvonuló legitimációs narratívát. Az említett „ajtón kívüliség” a rendezvény exkluzivitására is vonatkozhatott, ugyanis 3000 forintos belépöjeggyel volt látogatható a program. Véleményem szerint ezzel az esetleges, kétkedésüket hangosan kinyilvánítókat is távol tarthatták. A belépőjegyes rendszernek és a honlapon, facebook-oldalakon terjesztett programleírásnak is köszönhető, hogy a látogatók között szemmel láthatóan nem volt, aki csak „betévedt” volna a rendezvényre: többen programmal a kezükben érkeztek. A nagytermes előadásokon az állandó részvevők száma 19 fö volt, akik már a megnyitó beszéden is ott voltak, a nap előrehaladtával a létszám folyamatosan nőtt. A legtöbben 15 óra körül tartózkodtak a rendezvényen, ezután a létszám lassan apadni kezdett. A korosztály vegyes volt; legtöbben 20 és 40 év közöttiek és a 60 év felettiek voltak jelen. Nemek tekintetében a nők voltak többségben.

$\mathrm{Az}$ első előadást akupunktúrával foglalkozó, praktizáló háziorvos és belgyógyász tartotta („Mire jó az akupunktúra?”). Bemutatásakor a moderátor kiemelte, hogy „M. háziorvosként a keleti gyógyászat világában is járatos" - ez az előadás illetve az előadó személye szintén a "gyógyító nap”, illetve maga a kortárs alternatív gyógyászat legitimációs narratívájába illeszkedik, mivel egyesítette a hivatalos orvoslás és az alternatív gyógyászat szegmenseit. Előadásában az orvos mérhető, tudományos eredményekkel mutatta be az akupunktúra indokoltságát a nyugati orvoslás módszereinek kiegészítőjeként. A két terület szintézisét megvalósító hivatalos orvosi gyakorlatára láthattunk ebben az előadásban példát (Kapitány - Kapitány 2013:97), amely, helyszínül szolgáló rendezvény tematikáját tekintve annak legitimációs törekvéseit is segítette.

Ezután „örömzene dobokkal” következett: a közönség körbeültetése után mindenki választott egy-egy afrikai dobot: a programot vezető zenetanár megfogalmazása szerint „,a dobolás cselekvo, ritmusteremtő terápia a testnek, léleknek, szellemnek”. A harmadik előadás kis szünet, a székek visszarendezése után vette kezdetét. A föszervező-moderátor baráti hangon köszöntötte a soron következő előadót (akupresszőr, fül-addiktológus, radiesztéta, Energyszakoktató) kitérve kiemelkedő természetgyógyászi képességeire. „M. egy angyal” - kijelentésével, valamint az előadó közelmúltbeli „hihetetlen” felépülésével a „csodás gyógyító” narratíváját idézte fel. Mint az előadásból megtudhattuk, az autóbalesetet szenvedett hölgy maga mászott ki a roncsok közül (,egy alig 40 centis lyukon préseltem ki magam”), rendkívül gyors ütemủ felépülésének ,az orvosok is csodájára jártak". Mindezt, elmondása szerint egyrészről rendkívül erős akaraterejének köszönhette. A csodás/mágikus képességű gyógyító toposza után saját gyógyulásának másik fontos összetevőjével illetve természetgyógyászi tevékenységének meghatározó tényezőivel, az Energy termékekkel ismertette meg hallgatóságát. Először az EpsteinBarr vírus terjedését és hatását mutatta be, melyről a hivatalos orvoslás alig tájékozatja a lakosságot, mindamellett bizonyos élelmiszerek elkerülésével és a megfelelő Energy termék fogyasztásával magunk orvosolhatjuk a fertőzést. Ezután különböző típusú betegségek, problémák és a gyógyításukhoz legmegfelelőbb növényekből készült étrendkiegészítők felsorolása következett. Elöadásának végén a tudatosság és a megfelelő táplálkozás fontosságára hívta fel a figyelmet. Kapitány Ágnes és Kapitány Gábor megállapítja, hogy az 1990 után „diadalutat járó” holisztikus szemléletmód ezredforduló utáni hatásának tudható be a kémiai gyógyszerekkel szembeni elutasítás (Kapitány - Kapitány 2013:97). Ezt az olvasatot közvetítette ez az előadás.

A következő előadás témája szintén az étkezés volt, de itt táplálékkiegészítők nem, csak konkrét ételek és elkészítési módok kerültek szóba. Az előadó egészségterapeuta jógaoktatóként a nap folyamán a kisteremben is tartott bemutatót. „Táplálkozz egészségesen, de hogyan?" címü bemutatójában az idényjellegü, lehetőleg nyersen fogyasztott zöldségek-gyümölcsök és a házi készítésű szendvicskrémek, mártások, turmixok, müzlik receptjeibe avatta be a hallgatóságot. Ezek fogyasztása „a test energetizálása, harmonizálása, a mindennapos jó közérzet fenntartása miatt fontos”. Előadásában kitért számos, hazánkban is őshonos gyógynövény hasznosságára is. Ezután az illóolajok hatásait mutatta be az „Esszenciákkal a testi és lelki egészségért” című előadás. Itt a növényi olajok élettani (izomla- 
zító, gyulladáscsökkentő stb.) hatása mellett ugyanolyan hangsúllyal került bemutatásra azok lelket „harmonizáló, nyugtató, hangulatot kiegyensúlyozó" hatása. A holisztikus szemlélet itt is megjelent, megtudhattuk ugyanis, hogy „minden egyes betegség, minden egyes tünet: jelzés. Jelzést ad valamiről, amit nem értettünk meg, ami csak a tudattalanunkban van".

A kistermes programok 16 órakor fejeződtek be, pontosan az olimpikon szereplése előtt. „Nyitott órák" elnevezéssel a kis tükrös teremben Hatha jóga, Chikung, thai jóga és Etka jóga kipróbálására nyílt lehetőség. Az oktatók/előadók röviden bemutatták az általuk űzött sport eredetét, a mozdulattípusokat, melyeket ki is próbálhatták az érdeklődők az 50 perces foglalkozásokon. Hasonlóan zajlottak a masszázsbemutatók (Yumeiho terápia, meridián-, talp- és „irodai frissíto"” masszázsok). Itt volt időbeli átfedés az egyes bemutatók között. A jógaórákra és a masszázsbemutatókra lehetséges volt előzőleg regisztrálni az adott oktatónál, illetve a facebookon. A könyvtár helyiségében az egyes szakértők saját asztalnál ülve fogadták az érdeklődőket, ahol lehetőség nyílt bensőségesebb beszélgetések keretében kipróbálni az alábbi szolgáltatásokat: Bach virágterápia, Mátrix energetika és angyalkártyák, tarot, numerológia, Bemer mérés, aromaterápia-illóolajok (ennek szakértője, aki „természetes gyógymódok terapeuta, szivárványfénnyel gyógyító, pilates oktató", a nagyteremben később előadást is tartott az illóolajokról). Az előteret az alábbi termékeket árusítók népesítették be: „gyógyító ásványok”, bio gyümölcslevek, One Year márkájú probiotikus vitaminok, Avon kézápoló termékek, Pí víz, kézzel készült szappanok, valamint büfé. ${ }^{3} \mathrm{Az}$ udvaron egy nagyobb standon kínálták környékbeli termelők, készítők tartósítószertől és mesterséges anyagoktól mentes élelmiszereit: húsfélék (mangalica termékek), tészták, rizs, olajak (dióolaj, tökmagolaj), batáta, füszerek, mézek, teafüvek, helyben sütött kenyér kóstolására, vásárlására volt itt lehetőség.

A nagytermi előadások közötti szünetek lehetőséget biztosítottak arra, hogy vásárolni, nézelődni is tudjanak a látogatók. Az árusítók köszöntése után előfordult, hogy a vásárló megemlítette egészségügyi panaszát, amelyre aztán az árus igyekezett terméket kínálni. Például:

3 Érdekesség, hogy az erre a rendezvényre olyan büfé települt ki, melynek ételkínálatában nem szerepelt biovagy házias termék: a szendvicsekben bolti felvágott és margarin volt - ezek egyik előadás szerint kifejezetten károsak.
Vevő1: „Én szétnézek, nekem leginkább a derekammal van bajom.

Árus1: „Erre ezt a vitaminkészítményt ajánlom. Gyógyszert szed rá?

Vevő1: Igen, műtöttek is, meg fájdalomcsillapítót szedek.

Árus1: Ez a kollagénes hatóanyag belülről táplálja, erősíti a porcokat, amellyel meg tudja elözni a további bajokat. Ez nemcsak tüneti kezelés."

Árus2: Ajánlhatom Önnek kóstolásra ezeket a természetes gyümölcsleveket?

Vevő2 (nézegeti az üvegeket): Nézem... ez milyen fajta?

Árus2: Ez homoktövis, amelynek nagyon magas C-vitamin és antioxidáns tartalma van, ami gyulladáscsökkentő. Emellett nagyon frissítő, savanykás íze van.

Vevő2: Köszönöm (megissza) finom. Nincs benne cukor (helyeslöen mondja). Nekem kicsit magas volt a cukrom, azért.

Árus2: Nincs, és tartósító és színezék sem.

Nemcsak a homoktövis italnál, hanem a tésztáknál, mangalica termékeknél is elhangzott a „nemcsak finom, de egészséges" kijelentés:

„Vevő (Vevő4-nek mondja): Nézd, ezek egészségesek. Nincs bennük művi anyag!

Árus3: Igen, és az állatok is rendes táplálékot, nem tápot kaptak.

Vevő3 (kóstol): A legjobb ez. Ilyet még nagyapáink ettek. Nem kell ide ízfokozó!

Vevő4 (Vevő3-nak mondja, elmenőben) Nem csak egészségesebbek, de finomabbak is ezek, mint a bolti húsok".

Az eladók és a vásárlók beszélgetései a nagytermi eladások legitimációs narratíváit tükrözték: a termékek/táplálékok máshogy illetve mélyebben hatnak, mint a gyógyszerek, valamint az étkek esetében a természetes forrás/eloállítás nem megy az ízvilág rovására.

A rendezvényt két fö narratíva határozta meg: a legitimációs és a „csináld magad” narratíva. A legitimációs narratíva a program facebook-oldalán is fellelhető, amint a kiállítókat mutatja be: „Érdemes mindenkinél nyitott szívvel elidőzni és ismerkedni az újjal, a jóval, az érdekessel”. Ez egybecseng a moderátor bevezető szavaival, melyek szerint: „mindenki törekedjen arra, hogy minél több új- 
donsággal ismerkedjen meg és gazdagítsa az életét”. Ezekben a kijelentésekben az esemény megrendezésének indoklása is meghúzódik: a fellehető érdekességek, a megismerhető újdonságok indokolják az ide látogatást. Ezek a jelzők általánosságban, (még) nem konkrétan az alternatív gyógyászathoz kapcsolva jelennek itt meg. Ezzel az fejeződik ki, hogy az esemény - és általa az alternatív gyógyászat illetve életmód - mindenki számára elérhető, értelmezhető, megismerni való terület.

A legitimációs narratíva következő, nagyobb terepe a hivatalos orvoslással való összevetés. A nagytermes előadásokban ez kétféleképpen jelent meg: a háziorvos-akupunktőr prezentációjában távol-keleti gyógyászati hagyomány kiegésziti a nyugati, hivatalos orvoslást; a természetgyógyász-szakoktató beszámolójában alternatív módszerek viszont túlszárnyalják azt. A programban utána következő egészségterapeuta-jógaoktató előadása szintén a „hivatalos vs. alternatív" összehasonlítás mentén legitimálta az utóbbira jellemző megoldásokat, de már a táplálkozás, az ételek és a gyógynövények felől megközelítve. Így előadásából egyúttal az udvaron és az előtérben kínált élelmiszerek „értelmezési keretét” is megkaphatta a hallgatóság: a vegyszer- és adalékanyagmentes, idényjellegü, házias táplálék és a gyógynövények ismerete testi-lelki egészségünk alapvető elemei. Az előzőekben idézett két párbeszéd az árusok és a vevők között (homoktövis és mangalicatermék vásárlásai) a legitimációs narratíva „gyakorlati megvalósulásait” tükrözik: a készítmények a mesterséges anyagok, illetve a cukor nélkül egészségesek, de ugyanolyan finomak, vagy még finomabbak, mint a bolti termékek. A testi egészség megtartása napjainkban elválaszthatatlanná vált a különféle gasztronómiai irányzatoktól: az „egészségtudatosság” eredménye a „bio”, legújabban pedig a paleolit táplálkozás (Kapitány - Kapitány 2013:126). A „gyógyító napon” az előbbire találhattunk számos példát.

A „Táplálkozz egészségesen, de hogyan?” címü előadás szervesen kapcsolódik a másik meghatározó narratívához: a saját készítésű ételek világa a „csináld magad" narratívát is képviselte. Ennek meghatározó fogalmai: a felfedezés, az önmegismerés, a testtudatosság, a személyesség az egész rendezvényt végigkísérték. E narratíva „gyakorlati megvalósulásai” közül a „gyógyító ásványok” standját emelném ki, ahol betegséghez, lelkiállapothoz és horoszkópjegyhez illö ásványékszert választhatott magának a vásárló.

A sokféle programot, szereplőt felvonultató „gyógyító nap” többféle módon ismertette meg a látogatókkal az alternatív gyógyászat és életmód szegmenseit: a nagytermi, frontális előadásokkal párhuzamosan a kisebb termek bensőségesebb közeget biztosítottak a látogatóknak a különféle módszerekkel való megismerkedésre. A nagytermi előadások között váltogatták egymást az elsősorban testi betegségekkel illetve a táplálkozással foglalkozó, orvos és szakértők által tartott prezentációk és a lelkivilágra összpontosító programok (közös dobzene, illóolajos előadás, tibeti hangfürdő). A kistermek masszázs- és jógabemutatói elsősorban a test mozg(at)ásáról szóltak, de ugyanakkor ezoterikusspirituális módszerekbe, kártyajóslásba, sorselemzésbe is bele lehetett kóstolni.

A nyelvhasználat, az előforduló kifejezések is többrétűséget tükröztek. Találkozhattunk az elöadások során az ezotéria rendszerébe illeszthető elvont fogalmakkal, mint az energia, energetika, energiaáramlás, harmónia/harmonizálás, tudattalan mező és a kereskedelemben kapható termékek neveivel egyaránt (pl. Energy termékek).

16 órakor vette kezdetét a „Kerekasztal beszélgetés Márton Anita sportolónkkal: belsö erö megtartása minden körülmények között”. A sportoló, mint díszvendég szereplése a rendezvényen a megelőző napokban a „gyógyító nap” facebook-oldalán külön posztban kapott helyet: „Elérkezett a nap, amikor bemutatjuk az esemény díszvendégét, a tápéi gyökerekkel rendelkező világbajnok atlétánkat, aki sporttörténelmet írt!"

A sportoló és szülőhelye közötti szoros kapcsolat korábbi rendezvényeken és a médiában több ízben nagy hangsúlyt kapott: „Bármerre jár, tápéinak vallja magát Márton Anita. Az olimpiai bronzérmes súlylököt nem kellett noszogatni, hogy találkozzon azokkal, akik talán a legelkötelezettebben szurkoltak neki a riói játékokon” (szeged. hu cikke: „Márton Anita mindig tápéi marad”)

"Tápé aranylánya egy kicsit hazament" címmel olvashatunk tudósítást a világbajnoki címet elnyert sportolót köszöntő ünnepségről, mely a „gyógyító nap” előtt bő egy hónappal zajlott (szeged.hu 2018. március 9.). Ebből megtudhatjuk, hogy „Tápén mindenki tudja, hány kilós golyóval löknek a nök az atlétikai versenyeken". A település önkormányzati képviselőjének szavait is idézi a cikk, melyek szerint: „Nem foglalkozunk Szegeddel, meg Békéscsabával, ${ }^{4}$ mi tápéinak tekintjük ezt az érmet".

A beszélgetésre nem a nagyteremben, hanem az előtérben került sor. Kis asztalnál foglalt helyet a moderátor díszvendég, előtte világbajnoki és olimpiai

4 Az olimpikon a Békéscsabai Atlétikai Klub versenyzője. 
érmei. Velük szemben ültek az érdeklődők, közöttük pedig a földön leterítve a 19, $62^{5}$ méter hosszú nemzetiszín szalag, melyet a március 8-án tartott ünnepségen dedikált a sportoló és írtak alá a tápaiak.

A beszélgetés kezdetén a sportoló („Tápé szülötte, büszkesége") és eredményeinek méltatása után a „belső erő” témája került terítékre. A díszvendég sportolói pályafutásának tükrében zajlott az eszmecsere az alábbi fogalmak körüljárásával: kitartás, motiváció, siker, önbizalom, kudarckezelés.

A programpont címében szereplő „belső erő” elörevetítette azt a fajta szintézist, amelyet a „gyógyító nap" alternatív-ezoterikus szcénában elhelyezkedő kínálata és a világklasszis sportoló mindenki által elismert teljesítménye között ez a beszélgetés megteremteni törekedett. A már említett fogalmak körüljárása - motiváció, kitartás, siker, önbizalom, kudarckezelés - kevéssé ezoterikus, mindinkább a napjainkban népszerü önsegítő illetve coaching stílusú diskurzus mentén zajlott. A korábban bemutatott legitimációs és a „csináld magad” narratívához ez a beszélgetés egyaránt kapcsolódott. A délelőtt és a kora délután elhangzottakat ez a program szélesebb perspektívában (sportsikerek, világhírnév) láttatta és híres személy, mint díszvendég szereplésével, szavaival egyfajta megvalósulásként lehetett rá tekinteni: ha van a sikernek a „belső erö" által elérhető receptje, az eredményt a díszvendég prezentálja. A „belső erőről” szóló beszélgetés elsősorban az önismeret, motiváció megközelítésével vált a „csináld magad” narratíva hordozójává: a sportteljesítményt mint emberi (pszichés) sikerteljesítményt írta le, amely saját céljaik mentén a hallgatóság számára is követhető példaként jelent meg.

A már említett coaching-attitűd, a sportoló személy(iség)ének előtérbe kerülése, a lelki erőnek és a motivációnak a sportteljesítmény előfeltételeként való megjelenítésére napjainkból Hosszú Katinka tevékenységében találhatunk példát. A többszörös világ- és olimpiai bajnok úszónő a fentieket az 'Iron Lady' self-brandjével, instagram- és facebook-oldalával reprezentálja. Ezeken a felületeken az edzések és versenyek előtti és utáni fotóival, de még az étkezés és pihenés megörökített pillanataival is üzeni, hogy a siker ára a folyamatos küzdelem és eltökéltség, ${ }^{6}$ a testi mellett pedig ugyanolyan

5 Utalva arra, hogy a sportoló 2018. március 2-án a birminghami fedett pályás világbajnokságon 19,62 méteres, új országos rekorddal lett világbajnok.

6 Ennek „szlogenje” a fotói alatt mindig megjeleno” rövidítés: hwapo (Hard work always pays off - azaz: A kemény munka mindig meghozza gyümölcsét). https:// www.facebook.com/katinkahosszu/ fontos a lelki erőnlét is. Mi sem bizonyítja jobban, hogy ebbe a diskurzusba illeszthető a sportoló szerepeltetése a „gyógyító napon”, kiegészítve a lokalitás, helyi identitás megnyilvánulásaival, mint az alábbi, 2018. március 8-i újságcikk, melynek címe „A világbajnok Márton Anitát már Hosszú Katinkához hasonlítják: A tápéi Heller Ödön Művelődési Házban köszöntötték Magyarország első világbajnok atlétáját, Márton Anitát. Rengeteg gratulációt kapott a szegedi klasszis, és olyan szeretet vette körül, mint az olimpiai bronzérmet követő, hasonló rendezvényen. (...) Szembesítettük az egyik legérdekesebb jelzővel, amit az elmúlt napokban olvastunk és hallottunk róla: atlétikában ő a mi Hosszú Katinkánk - vallják, hiszen a 2014-es EB óta egy kivétellel minden nagy nemzetközi viadalról éremmel tért haza. - Örülök, ha így látják az emberek, de ettől még ugyanúgy szeretném végezni a munkát, ahogy eddig. Szerintem azért merülhetett fel ez az összehasonlítás, mert látják, hogy a versenyeken a lehető legjobbkor hozom ki magamból a maximumot. Ez csak kis részben adottság, a küzdőszellem ennél is fontosabb. Mivel itthon nem tudnak megszorongatni, megtanultam, hogyan küzdjek akkor is a maximumért, ha nincs tétje. Így érhettem el az utolsó lökésnél az országos csúcsot - mondta a 19,62 méteres eredményről, a 20 méteres álomhatárról pedig megjegyezte: inkább nyáron szeretné elérni” ?

A díszvendég szereplése után tibeti hangtálak zenéjével, azaz „hangfürdővel” zárult a nap.

A „gyógyító nap” a címében is kifejezett holisztikus szemléletmódot képviselve különböző kortárs alternatív gyógyászati módszereket vonultatott fel, melyeket összefüggésben tárgyalt-tálalt a különféle, életmódot illető (táplálkozás, testkultúra) vonatkozó konkrét megoldásokkal. Kínálatának színesítéséhez és célkitűzéseinek legitimációjához sportoló szerepeltetése járult hozzá, mely során a helyi identitás és a lokalitás is hangsúlyt kapott.

Az előadások alatt használt T/1. személyben való beszéd, a közös programok (dobolás, jóga) és a szakértők, árusok és látogatók közötti négyszemközti konzultációk lehetőségei egyfajta közösségkonstrukciós törekvésként is értelmezhetők. Ez és az általuk közvetített „csináld magad” narratívával a „gyógyító nap" olyan kulturális viselkedést képvisel, melybe a látogatók mint „önismerettel rendelkező, egészségéért tenni vágyó" ${ }^{\prime \prime}$ egyénekként kapcsolódhatnak be.

7 http://www.delmagyar.hu/sport/a_vilagbajnok_ marton_anitat_mar_hosszu_katinkahoz hasonlitjak/2552498/

8 Részlet az egyik jógabemutató szövegéből. 


\section{Források}

https://szegedma.hu/2010/06/a-kormorannalunnepel-tape

http://www.delmagyar.hu/sport/a_vilagbajnok_ marton_anitat_mar_hosszu_katinkahoz_ hasonlitjak/2552498/

https://szeged.hu/hirek/22745/tape-aranylanyaegy-kicsit-hazament

https://szeged.hu/hirek/19422/marton-anitamindig-tapei-marad

II. Elixirek, esszenciák Gyógyitó Nap az egészségedért! Facebook-oldal: https://www.facebook. com/events/786923174846697/

Hosszú Katinka facebook-oldala: https://www. facebook.com/katinkahosszu/

\section{Felhasznált szakirodalom}

Juhász Antal szerk. 1971 Tápé története és néprajza. Tápé Község Tanácsa, Tápé.

Kapitány Ágnes - Kapitány Gábor 2013 Látható és láthatatlan világok az ezredfordulón és utána. Typotex, Budapest.

Keszeg Vilmos - Czégényi Dóra szerk. 2010 A beteg ember. Betegségek, betegek és gyógyitók. Mentor Kiadó, Marosvásárhely.

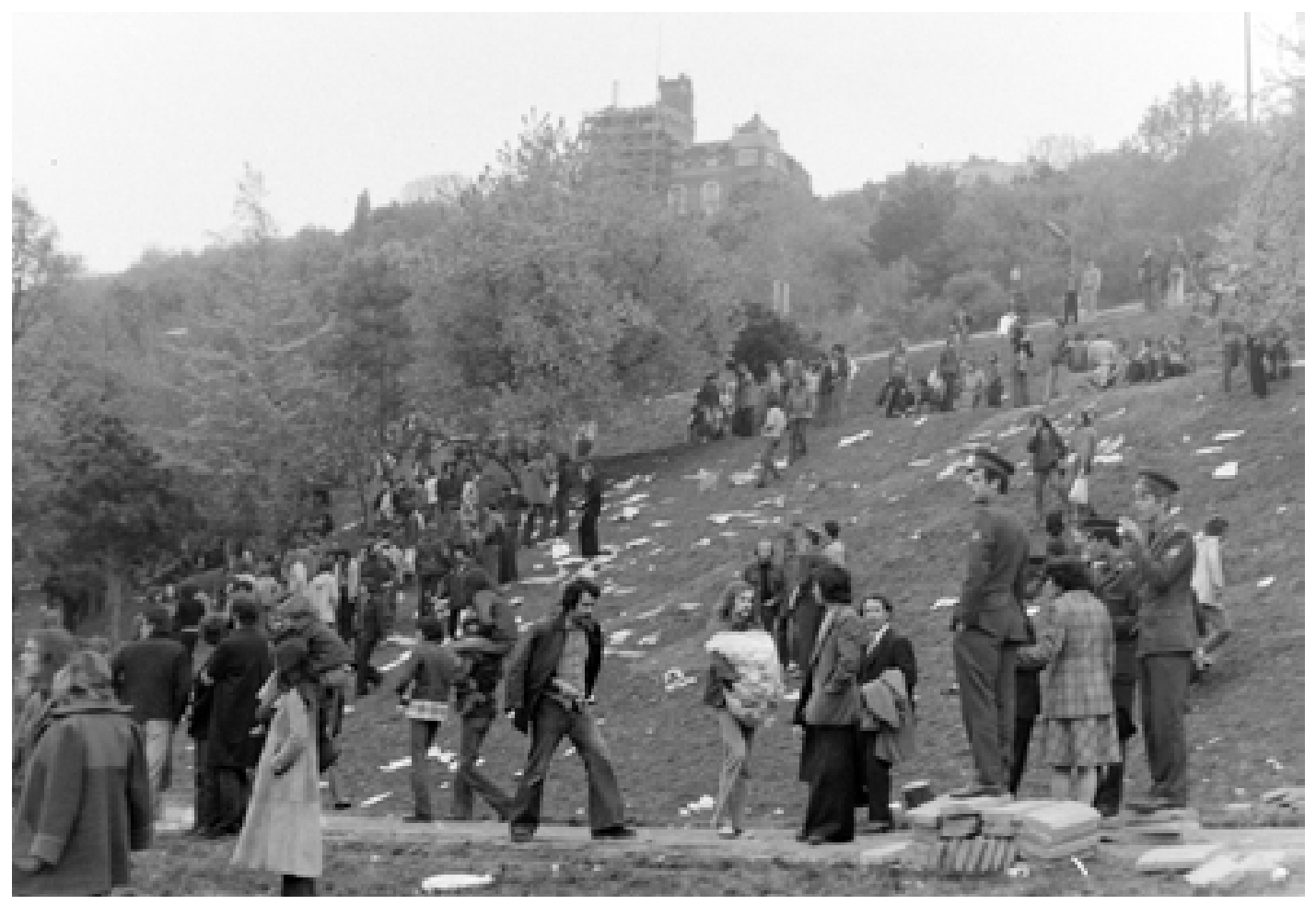

